\title{
Protein intake in infancy is not associated with adiposity at 4 years of age: findings from the Southampton Women's Survey
}

\author{
Sian Robinson, Sarah Crozier, Lynne Marriott, Nick Harvey, Hazel Inskip, Keith Godfrey \\ and Cyrus Cooper \\ University of Southampton, Southampton, UK
}

\begin{abstract}
A high protein intake in infancy has been associated with an increased risk of obesity in later childhood ${ }^{(1)}$. This finding is of potential concern in the UK where protein intakes are high in infancy, and much greater than estimated protein requirements ${ }^{(2)}$. To date the evidence base that links protein intakes to obesity risk has relied mainly on BMI and skinfold thickness as indirect measures of adiposity; in one small study using dual-energy X-ray absorptiometry (DXA) measures of body fat no association was found between protein intake in infancy and percentage body fat at 10 years $^{(3)}$.

The aim of the present study was to examine the relationship between protein intakes assessed at 6 and 12 months and fat mass determined by DXA at the age of 4 years in a large general-population sample of children born to women in the Southampton Women's Survey (SWS). The SWS is a study of 12583 non-pregnant women aged 20-34 years resident in the city of Southampton, UK. Babies born to women in the SWS are followed up at 6 and 12 months of age. Infant diet is assessed using administered FFQ, validated by comparison with $4 \mathrm{~d}$ weighed-diet diaries kept for fifty infants aged 6 months and fifty infants aged 12 months ${ }^{(4,5)}$. Fat mass was adjusted for height by calculating a fat mass index ${ }^{(6)}$. A total of 556 children born between 1999 and 2003 were included in the analyses.

Median protein intakes (g/d) at 6 and 12 months of age were 20.2 (interquartile range (IQR) 17.3-24.1) and 39.9 (IQR 33.3-48.2) respectively. Protein intake at 6 months was positively related to fat mass at 4 years of age $(P=0.026)$, but this relationship was not robust to adjustment for the effects of confounding influences (including birth weight and maternal smoking in pregnancy), and there was no relationship between protein intake at 6 months and fat mass index. Protein intake at 12 months was not related to fat mass or to fat mass index at 4 years of age.

In common with an earlier report using DXA-assessed measures of fat mass in childhood ${ }^{(3)}$, no association was found between protein intake in infancy and later adiposity. The data do not support the hypothesis that early protein intake influences risk of obesity in later childhood.
\end{abstract}

1. Rolland-Cachera MF, Deheeger M, Akrout M \& Bellisle F (1995) Int J Obes (Lond) 19, 573-578.

2. World Health Organization (2007) Protein and Amino Acid Requirements in Nutrition. WHO Technical Report Series no. 935. Geneva: WHO.

3. Hoppe C, Molgaard C, Thomsen BL, Juul A \& Michaelsen KF (2004) Am J Clin Nutr 79, 494-501.

4. Marriott LD, Robinson SM, Poole J, Borland SE, Godfrey KM, Law CM, Inskip HM \& SWS Study Group (2008) Public Health Nutr 11, 751-756.

5. Marriott LD, Inskip HM, Borland SE, Cooper C, Godfrey KM, Law CM \& Robinson SM (2008) Proc Nutr Soc 67, E172.

6. Wells JC, Cole TJ \& ALSPAC Study Team (2002) Int J Obes (Lond) 26, 947-952. 